\title{
Addition of D-penicillamine, hypotaurine, and epinephrine (PHE) mixture to IVF medium maintains motility and longevity of bovine sperm and enhances stable production of blastocysts in vitro
}

\author{
Sung-Sik KANG ${ }^{1)}$, Keisuke KOYAMA ${ }^{2)}$, Weiping HUANG ${ }^{1)}$, Yinghua YANG ${ }^{1}$, \\ Yojiro YANAGAWA ${ }^{1)}$, Yoshiyuki TAKAHASHI ${ }^{1,3)}$ and Masashi NAGANO ${ }^{1)}$ \\ 1) Laboratory of Theriogenology, Department of Veterinary Clinical Sciences, Graduate School of Veterinary Medicine, \\ Hokkaido University, Sapporo 060-0818, Japan \\ 2) Dairy Cattle Group, Konsen Agricultural Experiment Station, Hokkaido Research Organization, Nakashibetsu 086-1135, \\ Japan \\ 3) Genetics Hokkaido Association, Sapporo 060-0040, Japan
}

\begin{abstract}
The present study aimed to establish an efficient system for bovine embryo production by in vitro fertilization (IVF) that can achieve stable normal fertilization and blastocyst developmental rates in any bull without optimization of the sperm concentration in IVF medium. We examined the effects of a PHE mixture $(20 \mu \mathrm{M}$ D-penicillamine, $10 \mu \mathrm{M}$ hypotaurine and $1 \mu \mathrm{M}$ epinephrine), theophylline $(2.5 \mathrm{mM})$, and sperm concentration $\left(1,2\right.$ or $5 \times 10^{6}$ cells/ml) on fertilization and blastocyst developmental rates. High cleavage rates (78.3 to $92.4 \%)$ and blastocyst developmental rates (31.9 to $62.0 \%)$ at day 7 were obtained in the presence of PHE and theophylline in IVF medium with a sperm concentration of $2 \times 10^{6} \mathrm{cells} / \mathrm{ml}$ using sperm from 9 bulls. In addition, the synergistic effect of PHE and theophylline on normal fertilization ( 2 pronuclei) was clarified at $12 \mathrm{~h}$ after IVF with a sperm concentration of $1 \times 10^{6}$ cells $/ \mathrm{ml}$. Moreover, high linearity, high flagellar beat cross frequency, and low amplitude of lateral head of motile sperm were found by computer-assisted sperm analysis. In conclusion, the combination of the PHE mixture and theophylline synergistically accelerates sperm motility and sperm penetration of bovine oocytes. Theophylline activates sperm motility with increasing intracellular cAMP. However, PHE prevents an excessive increase of cAMP and maintains sperm motility without hyperactivation. When the combination of PHE and theophylline is added to IVF medium at a sperm concentration of $2 \times 10^{6}$ cells $/ \mathrm{ml}$, we can achieve stable normal fertilization and blastocyst development in any bull.
\end{abstract}

Key words: computer-assisted sperm analysis (CASA), In vitro fertilization (IVF), Oocyte, PHE, Theophylline

(J. Reprod. Dev. 61: 99-105, 2015)

$\mathbf{F}$ or in vitro fertilization (IVF) of bovine oocytes, IVF medium supplemented with heparin was conventionally used [1]. Bovine sperm incubated with heparin in vitro can be induced to undergo the acrosome reaction and penetrate oocytes more effectively than sperm incubated without heparin [2]. However, IVF with heparin was shown to require optimization of the sperm concentration for individual bulls [1], and it exhibited large variations in penetration [3], cleavage and blastocyst rates in each bull [4]. For the practical use of a small number of valuable sperm such as sex-sorted sperm and cryopreserved sperm from dead bulls [5], it is difficult to optimize the sperm concentration in each bull. Therefore, we should establish an effective IVF system without the need for optimization of the sperm concentration for individual bulls.

A mixture of D-penicillamine, hypotaurine, and epinephrine

Received: July 16, 2014

Accepted: November 17, 2014

Published online in J-STAGE: December 13, 2014

(C)2015 by the Society for Reproduction and Development

Correspondence: M Nagano (e-mail: mnaga@vetmed.hokudai.ac.jp)

This is an open-access article distributed under the terms of the Creative Commons Attribution Non-Commercial No Derivatives (by-nc-nd) License $<$ http://creativecommons.org/licenses/by-nc-nd/3.0/>.
(PHE) [6] has often been added to IVF medium with heparin. This supplementation shortened the time required for oocyte penetration [7] and increased the cleavage rate compared with the results without PHE [8]. In addition, it was reported that the addition of PHE to IVF medium improved motility and sperm parameters associated with bull fertility examined by computer-assisted sperm analysis (CASA) [9]. Some reports have demonstrated that D-penicillamine in IVF medium extended the lifespan of bovine sperm [10] and that hypotaurine played a role as an inhibitor of reactive oxygen species and induced motile sperm reactivation in the golden hamster [11]. Epinephrine, a kind of catecholamine, might stimulate soluble adenylyl cyclase and increase the concentration of cAMP in the cytoplasm of sperm [12], and increased cAMP might accelerate the beating of flagella to promote motility in mice [13]. However, the effects of a PHE mixture on sperm motility parameters and cAMP production in spermatozoa are not clear.

Theophylline also increases the concentration of cAMP in the cytoplasm of sperm by inhibiting phosphodiesterase (PDE) and stimulates sperm motility [14]. It has been demonstrated that a stable and high fertilization rate [15] and a blastocyst developmental rate of about $40 \%$ [16-18] were achieved by adding theophylline to bovine IVF medium at a fixed sperm concentration of $5 \times 10^{6}$ 
cells/ml recovered by a Percoll gradient (45 and 90\%) procedure. However, in the case of IVF with a low dose of sperm, such as sex-sorted sperm $\left(2.1 \times 10^{6}\right.$ cells/straw $)$ [19], the number of motile sperm might be insufficient for an IVF protocol using medium supplemented only with theophylline. In a previous study, we reported that the combination of PHE and theophylline resulted in high normal fertilization, cleavage, and blastocyst rates $(84.6,81.1$, and 51.6\%, respectively) for bovine IVF using $2 \times 10^{6}$ cells $/ \mathrm{ml}$ of sperm [20]. However, in our previous report [20], we used sperm derived from only one bull. Also the effect of the combination of a PHE mixture and theophylline on fertilization was not examined in detail.

In the present study, to establish an efficient system for bovine embryo production by IVF without optimization of the sperm concentration for sperm derived from any bull, we examined the effects of a PHE mixture, theophylline, and sperm concentration $\left(1,2\right.$ or $5 \times 10^{6}$ cells $\left./ \mathrm{ml}\right)$ on fertilization, cleavage, and blastocyst development. In addition, we evaluated the effects of the PHE mixture and theophylline on sperm motility and the intracellular cAMP concentration of spermatozoa.

\section{Materials and Methods}

\section{Chemicals}

All the chemicals used in this study were purchased from SigmaAldrich (St. Louis, MO, USA), unless otherwise stated.

\section{In vitro maturation and fertilization}

IVM of bovine oocytes was performed as described previously [17]. In brief, cumulus-oocyte complexes (COCs) aspirated from follicles ( 2 to $8 \mathrm{~mm}$ in diameter) of slaughterhouse-derived ovaries were cultured for $22 \mathrm{~h}$ in a droplet (about $10 \mathrm{COCs} / 50 \mu \mathrm{l}$ ) of maturation medium under a humidified atmosphere of $5 \% \mathrm{CO}_{2}$ in air at $39 \mathrm{C}$. The maturation medium consisted of HEPES-buffered TCM-199 (Invitrogen, Grand Island, NY, USA) supplemented with $10 \%$ fetal calf serum (FCS) (Invitrogen), $0.2 \mathrm{mM}$ sodium pyruvate, 0.02 units/ $\mathrm{ml}$ follicle-stimulating hormone (from porcine pituitary), $1 \mu \mathrm{g} / \mathrm{ml}$ estradiol- $17 \beta$ and $50 \mu \mathrm{g} / \mathrm{ml}$ gentamicin sulfate. IVF was conducted according to a procedure described previously [21]. Briefly, after the thawing of frozen semen from 9 bulls (A to I), motile sperm were separated using a Percoll (GE Healthcare, Buckinghamshire, UK) gradient (45 and 90\%). Matured COCs were co-incubated with motile sperm in droplets $(10-13 \mathrm{COCs} / 100 \mu \mathrm{l})$ of modified Brackett and Oliphant ( $\mathrm{mBO}$ ) isotonic medium [21] containing $3 \mathrm{mg} / \mathrm{ml}$ fatty acid-free BSA and supplemented with $2.5 \mathrm{mM}$ theophylline and/ or PHE $(20 \mu \mathrm{M}$ D-penicillamine, $10 \mu \mathrm{M}$ hypotaurine and $1 \mu \mathrm{M}$ epinephrine) [8] at $39 \mathrm{C}$ under a humidified atmosphere of $5 \% \mathrm{CO}_{2}$, $5 \% \mathrm{O}_{2}$ and $90 \% \mathrm{~N}_{2}$. All culture droplets were covered with paraffin oil (Nacalai Tesque, Kyoto, Japan). The final sperm concentration (1, 2 , or $5 \times 10^{6}$ cells $/ \mathrm{ml}$ ), co-incubation time (12 or $18 \mathrm{~h}$ ), and treatment with PHE and theophylline are described in the experimental design.

\section{Examination of spermatozoon penetration and in vitro culture of presumptive zygotes after IVF}

In vitro culture (IVC) of presumptive zygotes was performed using procedures that were basically the same as described previously [21]. After co-incubation with sperm, zygotes were freed from cumulus cells by vortexing. To evaluate sperm penetration, presumptive zygotes of each experiment group were fixed with ethanol:acetic acid at a ratio of $3: 1$ and stained with $1 \%$ aceto-orcein solution as described previously [22]. Oocytes having an enlarged sperm head(s) or male pronucleus(ei) were defined as penetrated by sperm, and the following categories of oocytes penetrated by sperm were recorded: 1) oocytes with male and female pronuclei with a corresponding sperm tail $(2 \mathrm{PN}), 2$ ) oocytes with more than two enlarged sperm heads or male pronuclei (polyspermy), and 3) oocytes other than $2 \mathrm{PN}$ and polyspermy, such as oocytes with an enlarged sperm head and anaphase II/telophase II chromosome or female pronucleus, or oocytes with a male pronucleus and telophase II chromosome (others). To evaluate the rates of development to blastocysts, cumulus-free presumptive zygotes were cultured for $150 \mathrm{~h}$ in droplets (25-30 presumptive zygotes/30 or $40 \mu \mathrm{l}$ ) using modified synthetic oviduct fluid, which contained $1 \mathrm{mM}$ glutamine, 12 essential amino acids for basal medium Eagle, 7 nonessential amino acids for minimum essential medium and $10 \mu \mathrm{g} / \mathrm{ml}$ insulin and was supplemented with $5 \mathrm{mM}$ glycine, $5 \mathrm{mM}$ taurine and $1 \mathrm{mM}$ glucose [21], and $3 \mathrm{mg} /$ $\mathrm{ml}$ fatty acid-free BSA instead of polyvinyl alcohol at $39 \mathrm{C}$ under a humidified atmosphere of $5 \% \mathrm{CO}_{2}, 5 \% \mathrm{O}_{2}$ and $90 \% \mathrm{~N}_{2}$. Cleavage and blastocyst rates were assessed after $30 \mathrm{~h}$ and $150 \mathrm{~h}$ of IVC, respectively. All embryos that developed to blastocysts were subjected to counting of their cell numbers using an air-drying method [22].

\section{Evaluation of sperm motility and sperm motility parameters by CASA}

Motile sperm separated using a Percoll gradient (45 and 90\%) and recovered motile sperm were incubated in $100-\mu$ l droplets of IVF medium (final concentration of $10 \times 10^{6}$ cells $/ \mathrm{ml}$ in $100-\mu$ d droplets) at $39 \mathrm{C}$ in $5 \% \mathrm{CO}_{2}, 5 \% \mathrm{O}_{2}$ and $90 \% \mathrm{~N}_{2}$. After incubation, $3 \mu \mathrm{l}$ of IVF medium from droplets was placed onto 4-chamber slides with a depth of $20 \mu \mathrm{m}$ (Art. No. SC 20-01-04-B, Leja, Nieuw-Vennep, Netherlands) on a micro warm plate (Kitazato, Shizuoka, Japan) at $37 \mathrm{C}$ for counting. Sperm in three fields (at least 100 spermatozoa) in a chamber were divided into motile and dead sperm, and the percentages of motile sperm and sperm motility parameters were evaluated using a CASA system (SMAS, DITECT, Tokyo, Japan). The evaluated sperm motility parameters were straight line velocity (VSL), curvilinear velocity (VCL), average path velocity (VAP), linearity $(\mathrm{LIN}=\mathrm{VSL} / \mathrm{VCL} \times 100)$, flagellar beat cross frequency (BCF) and amplitude of lateral head (ALH).

\section{Evaluation of intracellular cAMP concentration of spermatozoa}

The intracellular cAMP concentration of sperm was measured using the cAMP Biotrak enzyme immunoassay system kit (RPN2251, Amersham, GE Healthcare, Life Sciences, UK) according to the protocol provided by the manufacturer. The microplate contained 12 $\times 8$-well strips coated with donkey anti-rabbit IgG. In brief, motile sperm recovered using a Percoll gradient (45 and 90\%) were incubated in $400 \mu \mathrm{l}$ of IVF medium (final concentration of $10 \times 10^{6}$ cells $/ \mathrm{ml}$ ) in a $1.5-\mathrm{ml}$ tube for $2 \mathrm{~h}$ at $39 \mathrm{C}$ under $5 \% \mathrm{CO}_{2}, 5 \% \mathrm{O}_{2}$ and $90 \% \mathrm{~N}_{2}$. After incubation, each aliquot was centrifuged at $500 \times \mathrm{g}$ for $5 \mathrm{~min}$, and the supernatant was removed. The sperm pellet was resuspended in $200 \mu \mathrm{l}$ of lysis buffer and mixed on a microplate shaker for 10 
min at room temperature. One hundred microliters of lysate and 100 $\mu \mathrm{l}$ of antiserum were added to the wells and incubated at $4 \mathrm{C}$ for $2 \mathrm{~h}$. After incubation, $100 \mu \mathrm{l}$ of cAMP-peroxidase conjugate was added to each well and incubated at $4 \mathrm{C}$ for $1 \mathrm{~h}$. All supernatant was aspirated, and all wells washed four times with $400 \mu$ of wash buffer using a microplate washer (Model 1575, Immunowash ${ }^{\mathrm{TM}}$, Bio-Rad Laboratories, Tokyo, Japan). One hundred and fifty microliters of enzyme substrate was added to all wells and mixed on a microplate shaker at room temperature for $1 \mathrm{~h}$. One hundred microliters of 1.0 $\mathrm{M}$ sulfuric acid was added to each well, the optical density was determined with a plate reader (iMarkTM, Bio-Rad Laboratories) at $450 \mathrm{~nm}$, and cAMP concentrations in each well were evaluated.

\section{Experimental design}

In experiment 1, to examine the effect of the PHE mixture and different sperm concentrations on sperm penetration and blastocyst development rates in sperm derived from various bulls, IVF medium containing theophylline was used. Some of the matured COCs were co-incubated with sperm derived from bulls A, B, and C at a concentration of 1,2 or $5 \times 10^{6}$ cells $/ \mathrm{ml}$ for $18 \mathrm{~h}$, and fertilization status was examined. Other presumptive zygotes were cultured, and cleavage and blastocyst development were examined. As controls for sperm penetration and blastocyst development, oocytes incubated at a sperm concentration of $5 \times 10^{6}$ cells $/ \mathrm{ml}$ supplemented only with theophylline were used. In addition, to confirm blastocyst development after IVF using a sperm concentration of $2 \times 10^{6}$ cells/ $\mathrm{ml}$ in IVF medium containing a combination of theophylline and PHE, presumptive zygotes fertilized with sperm from six bulls (D to I) were cultured.

In experiment 2, to examine the effect of the PHE mixture and theophylline on sperm fertilizability in detail, matured COCs were co-incubated with sperm at a concentration of $1 \times 10^{6}$ cells $/ \mathrm{ml}$ (bulls A and I) for $12 \mathrm{~h}$ in IVF medium with or without PHE and/ or theophylline. Sperm of bull A showed similar 2PN rates among sperm concentrations of 1,2 and $5 \times 10^{6}$ cells $/ \mathrm{ml}$ for $18 \mathrm{~h}$ of IVF, irrespective of PHE and theophylline addition, in experiment 1. In addition, to confirm the effect of the PHE mixture and theophylline on sperm activity, after incubation $(0,2,4,6$, and $8 \mathrm{~h})$ of sperm of bull I, sperm motility was evaluated by CASA. For evaluation of sperm motility parameters, motile sperm with a VSL of $\geq 25 \mu \mathrm{m} /$ $\sec (50.49$ to $75.32 \%)$ were selected, as it has been recognized that motile sperm having a VSL of less than $25 \mu \mathrm{m} / \mathrm{sec}(25.51$ to $40.51 \%$ ) are probably not related to fertilization (Fig. 1).

To examine the effect of PHE and theophylline on the intracellular cAMP concentration of spermatozoa (bull I), the intracellular cAMP concentration of sperm was evaluated after $2 \mathrm{~h}$ of incubation in IVF medium with or without PHE and theophylline. As a control, sperm immediately after Percoll treatment $(0 \mathrm{~h})$ were used. All experiments in each group were carried with at least 3 replicates.

\section{Statistical analysis}

Sperm penetration rates (total penetration, 2PN, and polyspermy rates) were compared among groups by Chi-square test. The percentages of cleavage and development to blastocysts, mean cell numbers in blastocysts, average sperm motility parameters, and the concentration of intracellular cAMP after $2 \mathrm{~h}$ of incubation

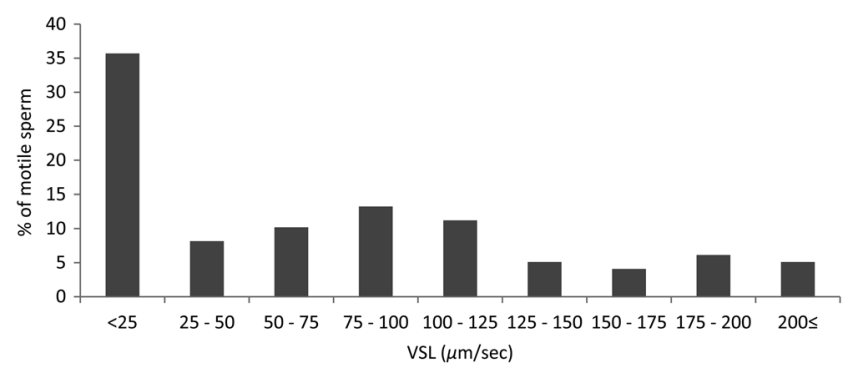

Fig. 1. Distribution of motile sperm based on straight line velocity (VSL) at $0 \mathrm{~h}$ of incubation. Sperm motility was analyzed immediately after treatment with a Percoll gradient (bull I).

were compared by one-way ANOVA followed by Tukey-Kramer's HSD test as a post hoc test. Intracellular cAMP concentrations at $0 \mathrm{~h}$ and $2 \mathrm{~h}$ in each treatment were compared by Dunnett's test. All analyses were performed using JMP Pro (version 10.0.2, SAS Institute, Cary, NC, USA).

\section{Results}

\section{Experiment 1}

The effects of PHE and sperm concentrations on penetration are shown in Table 1. In bull A, the $2 \mathrm{PN}$ rates were similar among different sperm concentrations $\left(1,2\right.$ and $5 \times 10^{6}$ cells $\left./ \mathrm{ml}\right)$, irrespective of PHE addition. In bulls $\mathrm{B}$ and $\mathrm{C}$ at a sperm concentration of $1 \times 10^{6}$ cells/ $\mathrm{ml}$ without $\mathrm{PHE}$, the total penetration and $2 \mathrm{PN}$ rates were the lowest among all experimental groups. In bull $\mathrm{C}$, at a sperm concentration of $1 \times 10^{6}$ cells $/ \mathrm{ml}$ with the PHE mixture, the total penetration rate was significantly lower than that of the control (sperm concentration of $5 \times 10^{6}$ cells $/ \mathrm{ml}$ without PHE; $\mathrm{P}<0.05$ ). In all bulls, the highest polyspermy rates were observed when PHE was added to IVF medium including theophylline at a sperm concentration of $5 \times 10^{6}$ cells $/ \mathrm{ml}$.

The effects of PHE and different sperm concentrations on embryonic development are shown in Table 2. At sperm concentrations of 1 and $2 \times 10^{6}$ cells $/ \mathrm{ml}$ (bulls $\mathrm{A}, \mathrm{B}$, and $\mathrm{C}$ ), there were no significant differences in cleavage rate, blastocyst rate and mean cell number in blastocysts compared with those at $5 \times 10^{6}$ cells $/ \mathrm{ml}$ without PHE (control). However, in bull $\mathrm{C}$, the cleavage rate at a sperm concentrations of $1 \times 10^{6}$ cells $/ \mathrm{ml}$ tended to be lower $(\mathrm{P}=0.08)$ than those at $2 \times 10^{6}$ cells $/ \mathrm{ml}$ and in the control. In addition, the mean cell numbers of blastocysts at a sperm concentration of $1 \times$ $10^{6}$ cells $/ \mathrm{ml}$ tended to be lower $(\mathrm{P}=0.13)$ than those at $2 \times 10^{6}$ cells $/ \mathrm{ml}$ and in the control in bull C. As shown in Table 3, after fertilization with a sperm concentration of $2 \times 10^{6}$ cells $/ \mathrm{ml}$ in the presence of PHE and theophylline, cleavage rates of 78.3 to $92.4 \%$ and blastocyst development rates of 31.9 to $62.0 \%$ were obtained from 6 bulls (D to I).

\section{Experiment 2}

In bulls A and I, after $12 \mathrm{~h}$ of co-incubation of COCs and sperm $\left(1 \times 10^{6}\right.$ cells $\left./ \mathrm{ml}\right)$, the total penetration and $2 \mathrm{PN}$ rates in the presence of PHE and theophylline were higher than those in the other experimental groups (Table 4; P $<0.05$ ). The effects of PHE and 
Table 1. The effects of the PHE mixture and sperm concentration on sperm penetration rate at $18 \mathrm{~h}$ after IVF using medium including theophylline

\begin{tabular}{|c|c|c|c|c|c|c|c|}
\hline \multirow{2}{*}{ Bulls } & \multirow{2}{*}{$\begin{array}{l}\text { Sperm concentration } \\
\qquad\left(\times 10^{6} \text { cells } / \mathrm{ml}\right)\end{array}$} & \multirow{2}{*}{ PHE } & \multirow{2}{*}{$\begin{array}{l}\text { No. of oocytes } \\
\text { (Replicates) }\end{array}$} & \multicolumn{4}{|c|}{ Percentages of } \\
\hline & & & & Total penetration & $2 \mathrm{PN}$ & Poly & Others* \\
\hline \multirow[t]{6}{*}{ A } & 1 & + & $31(3)$ & $100.0^{\mathrm{a}}$ & 74.2 & $9.4^{\mathrm{ab}}$ & $16.4^{\mathrm{a}}$ \\
\hline & & - & $31(3)$ & $84.2^{\mathrm{b}}$ & 75.1 & $0^{\mathrm{b}}$ & $9.1^{\mathrm{ab}}$ \\
\hline & 2 & + & $31(3)$ & $97.0^{\mathrm{ab}}$ & 68.2 & $13.0^{\mathrm{ab}}$ & $15.8^{\mathrm{a}}$ \\
\hline & & - & $31(3)$ & $96.7^{\mathrm{ab}}$ & 77.0 & $10.0^{\mathrm{ab}}$ & $9.7^{\mathrm{ab}}$ \\
\hline & 5 & + & $42(3)$ & $97.8^{\mathrm{ab}}$ & 75.9 & $21.8^{\mathrm{a}}$ & $0^{\mathrm{b}}$ \\
\hline & & - & $37(3)$ & $100.0^{\mathrm{a}}$ & 87.0 & $13.0^{\mathrm{ab}}$ & $0^{\mathrm{b}}$ \\
\hline \multirow[t]{6}{*}{$\mathrm{B}$} & 1 & + & $31(3)$ & $95.8^{\mathrm{a}}$ & $78.7^{\mathrm{a}}$ & $4.2^{\mathrm{a}}$ & $13.0^{\mathrm{a}}$ \\
\hline & & - & $32(3)$ & $59.4^{\mathrm{b}}$ & $50.0^{\mathrm{b}}$ & $0^{\mathrm{a}}$ & $9.4^{\mathrm{ab}}$ \\
\hline & 2 & + & $34(3)$ & $93.9^{\mathrm{a}}$ & $82.5^{\mathrm{a}}$ & $11.5^{\mathrm{ab}}$ & $0^{\mathrm{b}}$ \\
\hline & & - & $33(3)$ & $97.0^{\mathrm{a}}$ & $84.8^{\mathrm{a}}$ & $6.4^{\mathrm{a}}$ & $5.8^{\mathrm{ab}}$ \\
\hline & 5 & + & $31(3)$ & $100.0^{\mathrm{a}}$ & $73.6^{\mathrm{ab}}$ & $23.0^{\mathrm{b}}$ & $3.3^{\mathrm{ab}}$ \\
\hline & & - & $42(4)$ & $95.0^{\mathrm{a}}$ & $81.7^{\mathrm{a}}$ & $9.2^{\mathrm{ab}}$ & $4.2^{\mathrm{ab}}$ \\
\hline \multirow[t]{6}{*}{$\mathrm{C}$} & 1 & + & $40(3)$ & $81.7^{\mathrm{ab}}$ & $73.3^{\mathrm{ab}}$ & $3.3^{\mathrm{a}}$ & $5.0^{\mathrm{ab}}$ \\
\hline & & - & $40(3)$ & $69.5^{\mathrm{a}}$ & $49.0^{\mathrm{b}}$ & $6.7^{\mathrm{a}}$ & $13.8^{\mathrm{a}}$ \\
\hline & 2 & + & $51(4)$ & $97.9^{\mathrm{c}}$ & $82.4^{\mathrm{a}}$ & $15.7^{\mathrm{ab}}$ & $0^{\mathrm{b}}$ \\
\hline & & - & $48(4)$ & $89.2^{\mathrm{bc}}$ & $79.2^{\mathrm{ab}}$ & $3.9^{\mathrm{a}}$ & $9.4^{\mathrm{ab}}$ \\
\hline & 5 & + & $35(3)$ & $97.0^{\mathrm{bc}}$ & $53.6^{\mathrm{b}}$ & $30.6^{\mathrm{b}}$ & $12.8^{\mathrm{a}}$ \\
\hline & & - & $32(3)$ & $100.0^{\mathrm{c}}$ & $80.8^{\mathrm{a}}$ & $15.9^{\mathrm{ab}}$ & $3.3^{\mathrm{ab}}$ \\
\hline
\end{tabular}

a, b, c Values with different letters within each bull differ significantly $(\mathrm{P}<0.05)$. ${ }^{*}$ Others: an enlarged sperm head with an anaphase II/telophase II chromosome or a male pronucleus was observed. 2PN, two pronuclei; poly, penetrated with more than two sperm.

Table 2. The effects of PHE and sperm concentration on blastocyst developmental rate when using IVF medium including theophylline

\begin{tabular}{ccccccc}
\hline Bulls & $\begin{array}{c}\text { Sperm concentration } \\
\left(\times 10^{6} \text { cells } / \mathrm{ml}\right)\end{array}$ & PHE & $\begin{array}{c}\text { No. of oocytes } \\
(\text { Replicates })\end{array}$ & \% cleavage & \% blastocysts & $\begin{array}{c}\text { Mean cell numbers in } \\
\text { blastocysts (n) }\end{array}$ \\
\hline A & 1 & + & $72(3)$ & $81.9 \pm 2.4$ & $44.5 \pm 8.7$ & $144.9 \pm 50.6(33)$ \\
& 2 & + & $71(3)$ & $86.2 \pm 8.8$ & $50.8 \pm 11.3$ & $148.9 \pm 62.3(36)$ \\
& 5 & - & $70(3)$ & $87.5 \pm 12.5$ & $54.6 \pm 11.5$ & $165.9 \pm 64.4(38)$ \\
\hline B & 1 & + & $112(4)$ & $72.2 \pm 6.3$ & $36.6 \pm 6.6$ & $174.8 \pm 60.3(41)$ \\
& 2 & + & $80(3)$ & $78.3 \pm 4.4$ & $50.0 \pm 13.3$ & $183.9 \pm 63.8(40)$ \\
& 5 & - & $157(6)$ & $81.5 \pm 9.7$ & $39.2 \pm 10.0$ & $169.1 \pm 69.6(24)$ \\
\hline C & 1 & + & $65(3)$ & $68.0 \pm 4.8$ & $24.8 \pm 15.2$ & $148.3 \pm 55.4(16)$ \\
& 2 & + & $91(3)$ & $86.8 \pm 3.1$ & $31.9 \pm 5.0$ & $191.2 \pm 77.0(29)$ \\
& 5 & - & $189(8)$ & $80.5 \pm 11.5$ & $30.4 \pm 8.0$ & $188.1 \pm 76.1(58)$ \\
\hline
\end{tabular}

Values are means \pm SD. Embryos derived from bulls A to $\mathrm{C}$ were cultured in $40-\mu 1$ droplets.

Table 3. Blastocyst development after IVF with a sperm concentration of $2 \times 10^{6}$ cells $/ \mathrm{ml}$ in IVF medium containing a combination of theophylline and PHE

\begin{tabular}{ccccc}
\hline Bulls & $\begin{array}{c}\text { No. of oocytes } \\
\text { (Replicates) }\end{array}$ & \% cleavage & \% blastocysts & $\begin{array}{c}\text { Mean cell numbers in } \\
\text { blastocysts (n) }\end{array}$ \\
\hline D & $74(3)$ & $84.1 \pm 4.4$ & $50.6 \pm 5.2$ & $153.5 \pm 62.6(37)$ \\
E & $80(3)$ & $92.4 \pm 4.1$ & $62.0 \pm 12.2$ & $143.1 \pm 54.1(50)$ \\
F & $87(3)$ & $86.1 \pm 3.9$ & $39.2 \pm 5.1$ & $161.7 \pm 59.4(34)$ \\
G & $200(7)$ & $80.8 \pm 9.2$ & $38.0 \pm 10.9$ & $170.3 \pm 69.3(76)$ \\
H & $114(4)$ & $91.3 \pm 10.3$ & $37.9 \pm 3.7$ & $127.2 \pm 68.9(33)$ \\
I & $125(5)$ & $87.9 \pm 11.3$ & $39.8 \pm 7.7$ & $153.0 \pm 62.5(49)$ \\
\hline
\end{tabular}

Values are means \pm SD. Embryos derived from bulls D to F and bulls G to I were cultured in $40-\mu \mathrm{l}$ and $30-\mu 1$ droplets, respectively. 
Table 4. The effects of PHE and theophylline on sperm penetration rate of bulls A and I at $12 \mathrm{~h}$ after IVF with a sperm concentration of $1 \times 10^{6} \mathrm{cells} / \mathrm{ml}$

\begin{tabular}{|c|c|c|c|c|c|c|c|}
\hline \multirow{2}{*}{ Bull } & \multicolumn{2}{|c|}{ Treatment } & \multirow{2}{*}{$\begin{array}{l}\text { No. of oocytes } \\
\text { (Replicates) }\end{array}$} & \multicolumn{4}{|c|}{ Percentages of } \\
\hline & Theophylline & PHE & & Total penetration & $2 \mathrm{PN}$ & Poly & Others* \\
\hline \multirow[t]{4}{*}{$\mathrm{A}$} & + & + & $35(3)$ & $77.1^{\mathrm{a}}$ & $42.9^{\mathrm{a}}$ & 14.3 & 22.7 \\
\hline & & - & $33(3)$ & $45.5^{\mathrm{bc}}$ & $12.1^{\mathrm{b}}$ & 0 & 33.3 \\
\hline & - & + & $33(3)$ & $54.5^{\mathrm{b}}$ & $9.1^{\mathrm{bc}}$ & 6.1 & 39.4 \\
\hline & & - & $32(3)$ & $28.1^{\mathrm{c}}$ & $0^{c}$ & 0 & 27.9 \\
\hline \multirow[t]{4}{*}{ I } & + & + & $55(5)$ & $60.3^{\mathrm{a}}$ & $28.1^{\mathrm{a}}$ & 0 & $32.2^{\mathrm{a}}$ \\
\hline & & - & $57(5)$ & $39.0^{\mathrm{b}}$ & $10.8^{\mathrm{b}}$ & 0 & $28.6^{\mathrm{a}}$ \\
\hline & - & + & $56(5)$ & $8.8^{\mathrm{c}}$ & $1.8^{\mathrm{c}}$ & 0 & $6.7^{b}$ \\
\hline & & - & $57(5)$ & $1.7^{\mathrm{c}}$ & $0^{\mathrm{c}}$ & 0 & $1.7^{\mathrm{b}}$ \\
\hline
\end{tabular}

a, b, c Values with different letters within each bull differ significantly $(\mathrm{P}<0.05) .{ }^{*}$ Others: an enlarged sperm head with an anaphase II/telophase II chromosome or a male pronucleus was observed. 2PN, two pronuclei; poly, penetrated with more than two sperm.

theophylline on sperm motility and sperm motility parameters are shown in Fig. 2. The total percentage of motile sperm decreased with increasing incubation period in all experimental groups; in particular, those at 6 and $8 \mathrm{~h}$ with only theophylline supplementation were significantly lower than those in the nontreatment (Fig. 2A; $\mathrm{P}<0.05$ ). On the other hand, in terms of the percentages of sperm moving at more than $25 \mu \mathrm{m} / \mathrm{sec}$ in the VSL, only PHE addition showed stable motility $(\sim 70 \%)$ during the experimental period, with low variation compared with the percentages in the nontreatment, theophylline addition, and combination of PHE and theophylline groups (Fig. 2B). The average VAP levels of sperm incubated with theophylline regardless of PHE addition were significantly increased at $2 \mathrm{~h}$ and decreased at $6 \mathrm{~h}$ compared with those in the nontreatment group (Fig. 2C; $\mathrm{P}<0.05$ ). Regardless of PHE addition to IVF medium, the average LIN at $2 \mathrm{~h}$ with theophylline was significantly higher than those in the nontreatment group and the PHE addition only group (Fig. 2D; P < 0.05). The average BCF with PHE and theophylline at $6 \mathrm{~h}$ was higher than those in the nontreatment group and the PHE addition only group (Fig. $2 \mathrm{E} ; \mathrm{P}<0.05$ ). The average ALH levels at 6 and $8 \mathrm{~h}$ with PHE and theophylline were significantly lower than those in the nontreatment group and the PHE addition only group (Fig. 2F; P $<0.05$ ).

As shown in Fig. 3, the mean intracellular cAMP concentration of sperm incubated with theophylline $\left(167.5 \pm 54.5 \mathrm{fmol} / 5 \times 10^{6}\right.$ cells; mean $\pm \mathrm{SD}$ ) at $2 \mathrm{~h}$ was significantly higher than for those incubated with PHE $\left(53.9 \pm 54.7 \mathrm{fmol} / 5 \times 10^{6}\right.$ cells $)$ and in the nontreatment group $\left(45.1 \pm 47.9 \mathrm{fmol} / 5 \times 10^{6}\right.$ cells; $\left.\mathrm{P}<0.05\right)$. However, the cAMP concentration of sperm incubated with PHE and theophylline $\left(117.3 \pm 92.9 \mathrm{fmol} / 5 \times 10^{6}\right.$ cells $)$ showed an intermediate value between those of sperm incubated with theophylline or PHE. The mean intracellular cAMP concentration of sperm incubated with theophylline only showed a significantly higher value than that at 0 $\mathrm{h}\left(68.2 \pm 19.9 \mathrm{fmol} / 5 \times 10^{6}\right.$ cells; $\left.\mathrm{P}<0.05\right)$.

\section{Discussion}

In bull $\mathrm{A}$, addition of PHE to the IVF medium at different sperm concentrations $\left(1,2\right.$, and $\left.5 \times 10^{6} \mathrm{cells} / \mathrm{ml}\right)$ did not affect $2 \mathrm{PN}$ rates at
A

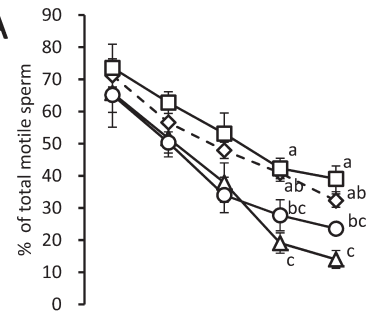

C 200

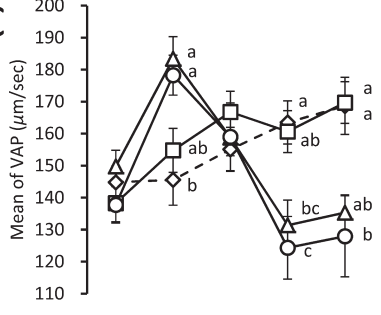

E

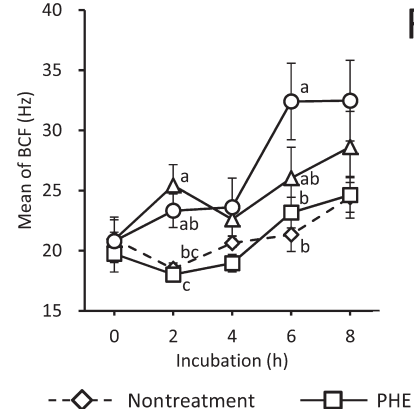

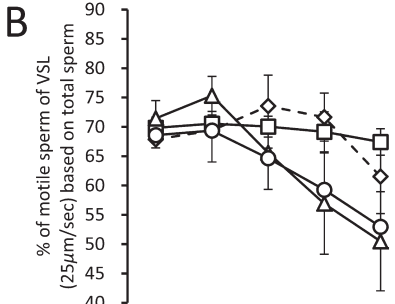

D

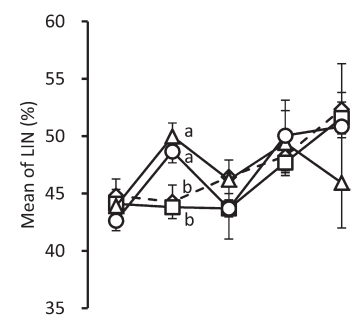

$\mathrm{F}$

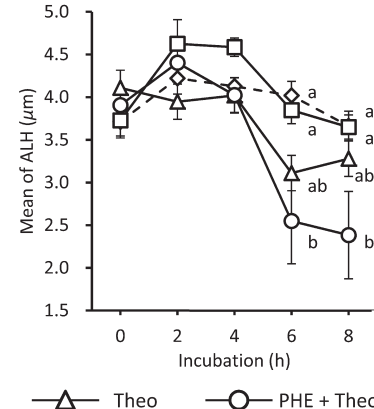

Fig. 2. The sperm motility and sperm motility parameters during incubation in IVF medium supplemented with or without PHE mixture and theophylline. A: \% of total motile sperm; B: \% of motile sperm with a VSL of $\geq 25 \mu \mathrm{m} / \mathrm{sec}$; C: mean VAP $(\mu \mathrm{m} / \mathrm{sec})$; D: mean LIN (\%); E: mean BCF (Hz); F: mean ALH $(\mu \mathrm{m})$. Values in panels $\mathrm{C}$ to $\mathrm{F}$ were calculated by using sperm that showed a VSL of $\geq 25 \mu \mathrm{m} / \mathrm{sec}^{\mathrm{a}}{ }^{\mathrm{a}, \mathrm{b}, \mathrm{c}}$ Values with different letters differ significantly $(\mathrm{P}<0.05)$. The error bar indicates the SEM. Nontreatment, $\mathrm{mBO}$ medium only; PHE, mixture of D-penicillamine, hypotaurine, and epinephrine; Theo, theophylline. VSL, straight line velocity; VAP, average path velocity; LIN, linearity (VSL/VCL [curvilinear velocity] $\times 100)$; $\mathrm{BCF}$, flagellar beat cross frequency; $\mathrm{ALH}$, amplitude of lateral head. 


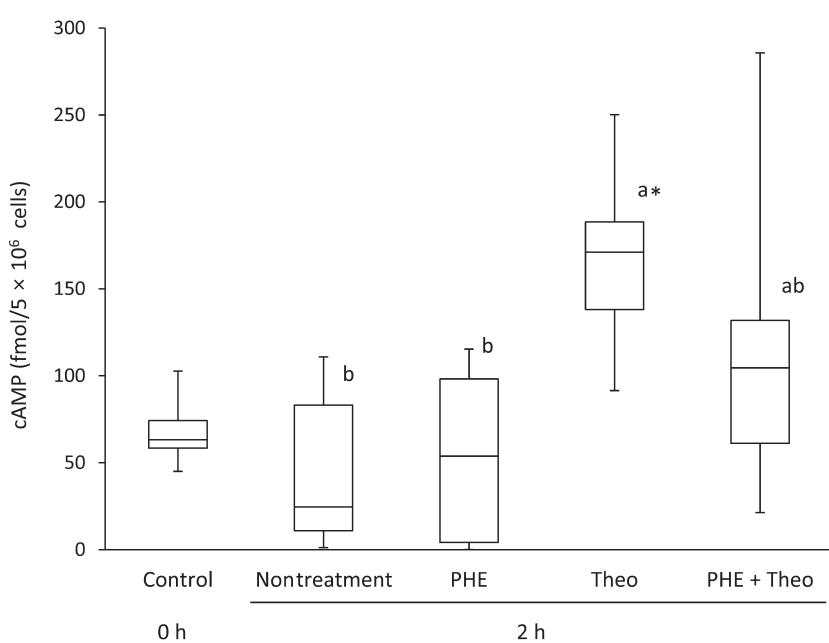

Fig. 3. Mean intracellular cAMP concentration in sperm at $2 \mathrm{~h}$ after incubation. Lines of the boxes delineate the 25th, 50th, and 75th percentiles, and the whiskers depict the 10th and 90th percentiles of a population. ${ }^{\mathrm{a}, \mathrm{b}}$ Different letters indicate a significant difference among groups $(\mathrm{P}<0.05) .{ }^{*}$ The asterisk indicates a significant difference from the control. Six replicates per group were performed. Control and nontreatment, $\mathrm{mBO}$ medium only; PHE, mixture of D-penicillamine, hypotaurine, and epinephrine; Theo, theophylline.

$18 \mathrm{~h}$ post insemination but did at $12 \mathrm{~h}$ post insemination. However, in bull $\mathrm{B}$ at $18 \mathrm{~h}$ post insemination, PHE addition was necessary to enhance total penetration and normal fertilization at a sperm concentration of $1 \times 10^{6}$ cells $/ \mathrm{ml}$. Meanwhile, in bull $\mathrm{C}$, the total penetration rate at a sperm concentration of $1 \times 10^{6}$ cells $/ \mathrm{ml}$ was not enhanced compared with that at a sperm concentration of $2 \times$ $10^{6}$ cells $/ \mathrm{ml}$ even though PHE was added to the IVF medium. In bulls $\mathrm{A}, \mathrm{B}$ and $\mathrm{C}$, addition of PHE to the IVF medium at a sperm concentration of $5 \times 10^{6}$ cells $/ \mathrm{ml}$ showed the highest polyspermy rate. These results indicate that, when the combination of PHE and theophylline is added to IVF medium, the sperm concentration can be reduced from $5 \times 10^{6}$ cells $/ \mathrm{ml}$ to $2 \times 10^{6}$ cells $/ \mathrm{ml}$, which can obtain a high and stable $2 \mathrm{PN}$ rate. In addition, after fertilization in the presence of PHE and theophylline with a sperm concentration of $2 \times$ $10^{6}$ cells $/ \mathrm{ml}$, we obtained a relatively high rate of normal fertilization ( 68.2 to $82.4 \%$ ) from 3 bulls and high cleavage (78.3 to $92.4 \%$ ) and blastocyst rates (31.9 to $62.0 \%$ ) from 9 bulls. From these results, a sperm concentration of $2 \times 10^{6}$ cells $/ \mathrm{ml}$ is recommended for use in IVF in the presence of PHE and theophylline in IVF medium, which can stably provide high rates of normal fertilization and blastocyst development using sperm collected from any bull.

In this study, we found a synergistic effect of PHE and theophylline on the fertilizability of sperm; namely, PHE and theophylline enhanced the sperm penetration ability and shortened the time to penetration, especially at a low concentration of sperm. In agreement with the present results, it was reported that sperm penetration ability [7] and cleavage rate [8] were enhanced by the addition of PHE to IVF medium including heparin. In the present study, analysis with the CASA system revealed that, in the presence of only theophylline, the percentage of total motile sperm became lower than that of the nontreatment group after $6 \mathrm{~h}$ of incubation; however, addition of PHE to the IVF medium with theophylline prevented the decrease in the percentage of total motile sperm. Sperm incubated in IVF medium with only PHE maintained a stable percentage (about 70\%) of motile sperm with a VSL of $\geq 25 \mu \mathrm{m} / \mathrm{sec}$ based on total sperm during the 8 $\mathrm{h}$ incubation period. We speculated that the addition of PHE to IVF medium maintains sperm motility. The averages of VAP and LIN at $2 \mathrm{~h}$ were increased in the presence of theophylline regardless of PHE addition compared with those in the nontreatment group. These results indicate that theophylline enhanced the progressive motility of sperm within a short period.

In the presence of PHE and theophylline at $6 \mathrm{~h}$ after incubation, average BCF was significantly higher compared with that in the nontreatment group. On the other hand, the average ALH of sperm incubated with the combination of PHE and theophylline at 6 and $8 \mathrm{~h}$ was significantly lower than that in the nontreatment group. This result is not consistent with a previous report describing that ejaculated sperm incubated in Tyrode's HEPES-buffered medium with heparin showed significantly high average ALH and BCF levels at 1 $\mathrm{h}$ to $4 \mathrm{~h}$ compared with those incubated in Tyrode's HEPES-buffered medium without heparin supplementation [23]. Chamberland et al. [23] suggested that the increases in BCF and ALH of sperm incubated with heparin in vitro could be related to the hyperactivation of sperm [23]. In addition, theophylline induced hyperactivation and the acrosome reaction in sperm of dogs [24] and enhanced the rate of sperm penetration into oocytes in humans [25]. The increase in $\mathrm{BCF}$ and decrease in ALH observed in the present study probably indicate that sperm incubated with PHE and theophylline acquire a high level of activity without hyperactivation.

It was previously reported that adenosine and catecholamine agonists might increase cAMP in the cytoplasm of sperm and accelerate the beating of flagella related to BCF in mice [12]. In the present study, theophylline, one of the PDE inhibitors, increased intracellular cAMP. In humans, pentoxifylline, another PDE inhibitor, also increased the intracellular cAMP content of sperm in a manner correlated to increases of BCF and ALH [26]. However, in the present study, the ALH of sperm incubated with PHE and theophylline at 6 and $8 \mathrm{~h}$ was suppressed compared with that of sperm incubated with only theophylline. Because sperm incubated with PHE and theophylline at $2 \mathrm{~h}$ showed a relatively low intracellular cAMP concentration compared with that of sperm incubated with only theophylline addition, we speculated that PHE activated an unknown signaling pathway to prevent the increase in intracellular cAMP and subsequently maintained sperm motility.

According to these hypotheses, sperm incubated with PHE and theophylline maintain high progressive motility. Therefore, these sperm have increased opportunities to encounter oocytes and subsequently penetrate them. Further study is needed to clarify the relationship between sperm motility parameters, intracellular cAMP content of sperm and not only IVF medium including theophylline and PHE mixtures, but also D-penicillamine, hypotaurine and epinephrine separately.

In conclusion, the combination of a PHE mixture and theophylline synergistically accelerates sperm motility and sperm penetration of bovine oocytes. Theophylline activates sperm motility with increasing 
intracellular cAMP. However, PHE prevents an excessive increase in cAMP and maintains sperm motility without hyperactivation. When the combination of PHE and theophylline is added to IVF medium at a sperm concentration of $2 \times 10^{6}$ cells $/ \mathrm{ml}$, we can obtain stable normal fertilization and blastocyst development rates using sperm from any bull.

\section{Acknowledgments}

This study was supported by a Grant-in-Aid for Scientific Research from the Japan Society for the Promotion of Science to M. Nagano (No. 25450441). We thank the Genetics Hokkaido Association for the donation of frozen bull sperm.

\section{References}

1. Parrish JJ. Bovine in vitro fertilization: in vitro oocyte maturation and sperm capacitation with heparin. Theriogenology 2014; 81: 67-73. [Medline] [CrossRef]

2. Parrish JJ, Susko-Parrish JL, First NL. Capacitation of bovine sperm by heparin: inhibitory effect of glucose and role of intracellular pH. Biol Reprod 1989; 41: 683-699. [Medline] [CrossRef]

3. Niwa K, Ohgoda $\mathbf{O}$. Synergistic effect of caffeine and heparin on in-vitro fertilization of cattle oocytes matured in culture. Theriogenology 1988; 30: 733-741. [Medline] [CrossRef]

4. Lu KH, Seidel GE Jr. Effects of heparin and sperm concentration on cleavage and blastocyst development rates of bovine oocytes inseminated with flow cytometrically-sorted sperm. Theriogenology 2004; 62: 819-830. [Medline] [CrossRef]

5. Selokar NL, Saini M, Palta P, Chauhan MS, Manik R, Singla SK. Hope for restoration of dead valuable bulls through cloning using donor somatic cells isolated from cryopreserved semen. PLOS ONE 2014; 9: e90755. [Medline] [CrossRef]

6. Hasler JF, Stokes JE. Effect of the presence or absence of percoll centrifugation; penicillamine, hypotaurine, and epinephrine; and heparin on in vitro production of bovine embryos. Reprod Fertil Dev 2013; 25: 259. [CrossRef]

7. Susko-Parrish JL, Wheeler MB, Ax RL, First NL, Parrish JJ. The effect of penicillamine, hypotaurine, epinephrine and sodium metabisulfite, on bovine in vitro fertilization. Theriogenology 1990; 33: 333. [CrossRef]

8. Miller GF, Gliedt DW, Rakes JM, Rorie RW. Addition of penicillamine, hypotaurine and epinephrine (PHE) or bovine oviductal epithelial cells (BOEC) alone or in combination to bovine in vitro fertilization medium increases the subsequent embryo cleavage rate. Theriogenology 1994; 41: 689-696. [Medline] [CrossRef]

9. Person CN, Lester TD, Person MD, Rorie RW. Effects of penicillamine, hypotaurine and epinephrine (PHE) on post-thaw bovine sperm parameters, as measured by computerassisted sperm analysis. AAES Research Series 2007; 553: 47-50.

10. Pavlok A. D-penicillamine and granulosa cells can effectively extend the fertile life span of bovine frozen-thawed spermatozoa in vitro: effect on fertilization and polyspermy.
Theriogenology 2000; 53: 1135-1146. [Medline] [CrossRef]

11. Boatman DE, Bavister BD, Cruz E. Addition of hypotaurine can reactivate immotile golden hamster spermatozoa. J Androl 1990; 11: 66-72. [Medline]

12. Schuh SM, Hille B, Babcock DF. Adenosine and catecholamine agonists speed the flagellar beat of mammalian sperm by a non-receptor-mediated mechanism. Biol Reprod 2007 77: 960-969. [Medline] [CrossRef]

13. Schuh SM, Carlson AE, McKnight GS, Conti M, Hille B, Babcock DF. Signaling pathways for modulation of mouse sperm motility by adenosine and catecholamine agonists Biol Reprod 2006; 74: 492-500. [Medline] [CrossRef]

14. Hoskins DD, Hall ML, Munsterman D. Induction of motility in immature bovine spermatozoa by cyclic AMP phosphodiesterase inhibitors and seminal plasma. Biol Reprod 1975; 13: 168-176. [Medline] [CrossRef]

15. Takahashi Y, First NL. In vitro fertilization of bovine oocytes in the presence of theophylline. Anim Reprod Sci 1993; 34: 1-18. [CrossRef]

16. Huang W, Nagano M, Kang S-S, Yanagawa Y, Takahashi Y. Prematurational culture with 3-isobutyl-1-methylxanthine synchronizes meiotic progression of the germinal vesicle stage and improves nuclear maturation and embryonic development in in vitrogrown bovine oocytes. J Reprod Dev 2014; 60: 9-13. [Medline] [CrossRef]

17. Kang S-S, Ofuji S, Imai K, Huang W, Koyama K, Yanagawa Y, Takahashi Y, Nagano M. The efficacy of the well of the well (WOW) culture system on development of bovine embryos in a small group and the effect of number of adjacent embryos on their development. Zygote 2014; 1-4: 1-4.; DOI [CrossRef]. [Medline]

18. Nagano M, Kang S-S, Koyama K, Huang W, Yanagawa Y, Takahashi Y. In vitro maturation system for individual culture of bovine oocytes using micro-volume multi-well plate. Jpn J Vet Res 2013; 61: 149-154. [Medline]

19. Rath D, Moench-Tegeder G, Taylor U, Johnson LA. Improved quality of sex-sorted sperm: a prerequisite for wider commercial application. Theriogenology 2009; 71: 22-29. [Medline] [CrossRef]

20. Koyama K, Kang S-S, Huang W, Yanagawa Y, Takahashi Y, Nagano M. Aging-related changes in in vitro-matured bovine oocytes: oxidative stress, mitochondrial activity and ATP content after nuclear maturation. $J$ Reprod Dev 2014; 60: 136-142. [Medline] [CrossRef]

21. Takahashi Y, Kanagawa H. Effects of glutamine, glycine and taurine on the development of in vitro fertilized bovine zygotes in a chemically defined medium. J Vet Med Sci 1998; 60: 433-437. [Medline] [CrossRef]

22. Takahashi Y, First NL. In vitro development of bovine one-cell embryos: Influence of glucose, lactate, pyruvate, amino acids and vitamins. Theriogenology 1992; 37: 963-978. [Medline] [CrossRef]

23. Chamberland A, Fournier V, Tardif S, Sirard MA, Sullivan R, Bailey JL. The effect of heparin on motility parameters and protein phosphorylation during bovine sperm capacitation. Theriogenology 2001; 55: 823-835. [Medline] [CrossRef]

24. Kawakami E, Arai T, Nakamura U. Effects of medium containing heparin and theophylline on capacitation and metabolic enzyme activities of ejaculated spermatozoa from dogs with asthenozoospermia. Anim Reprod Sci 1999; 54: 251-259. [Medline] [CrossRef]

25. Loughlin KR, Agarwal A. Use of theophylline to enhance sperm function. Arch Androl 1992; 28: 99-103. [Medline] [CrossRef]

26. Calogero AE, Fishel S, Hall J, Ferrara E, Vicari E, Green S, Hunter A, Burrello N, Thornton S, D'Agata R. Correlation between intracellular cAMP content, kinematic parameters and hyperactivation of human spermatozoa after incubation with pentoxifylline. Hum Reprod 1998; 13: 911-915. [Medline] [CrossRef] 